\title{
Processed Meat
}

National Cancer Institute

\section{Source}

National Cancer Institute. Processed Meat. NCI Thesaurus. Code C126483.

Meat that has been modified to either extend its shelf life or change its taste. 